\title{
Comparative Bioavailability of Two Brands of Ofloxacin in Healthy Human Volunteers
}

\author{
Rajani Shakya ${ }^{1 *}$, Manila Hada ${ }^{1}$, Panna Thapa ${ }^{1}$, R. N. Saha ${ }^{2}$
}

${ }^{1}$ Department of Pharmacy, Kathmandu University, Nepal

${ }^{2}$ BITS, Pilani, Rajasthan, India

\section{Abstract}

The relative bioavailability and pharmacokinetics of a locally manufactured (Oquin) and reference (Zanocin) formulations of ofloxacin were compared. Each volunteer received a single dose of $200 \mathrm{mg}$ ofloxacin tablet, test or reference with a 7 days washout period. Multiple blood samples were collected and plasma concentrations of ofloxacin were analyzed by high performance liquid chromatography technique.

Following oral administration of both formulations, there was rapid and extensive oral absorption from gastrointestinal tract achieving maximum serum concentration within $2 \mathrm{hrs}$. The concentration-time profile generated by the two products was found to be superimposable. Peak plasma concentration $\left(\mathrm{C}_{\max }\right)$, area under the serum concentration-time curve $\left(\mathrm{AUC}_{0-24}\right)$, area under the serum concentration-time curve extrapolated to infinity $\left(\mathrm{AUC}_{0-\infty}\right)$ and serum elimination halflife $\left(\mathrm{t}_{1 / 2}\right)$ were $1.98 \pm 0.213$ and $1.82 \pm 0.194 \mu \mathrm{g} / \mathrm{ml}, 13.19 \pm 1.45$ and $12.56 \pm 0.965 \mu \mathrm{g} . \mathrm{hr} / \mathrm{ml}, 13.86 \pm 1.49$ and $13.14 \pm$ $0.959 \mu \mathrm{g} . \mathrm{hr} / \mathrm{ml}, 5.55 \pm 1.37$ and $5.55 \pm 0.715 \mathrm{hr}$ for Oquin and Zanocin, respectively.

The result indicates that these two formulations have similar rate as well as extent of absorption. Hence these two products can be said to have comparable bioavailability.

Keywords: Ofloxacin; Pharmacokinetics; Bioavailability

\section{Introduction}

Ofloxacin [OFX] is a well known synthetic carboxyquinolone antimicrobial agent with a broad antimicrobial spectrum against gram positive and gram-negative bacteria and is considered safe. The bactericidal action of OFX results from interference with enzyme DNA gyrase that is needed for the synthesis of bacterial DNA (Okeri and Arhewoh, 2008). Its favorable pharmacokinetic feature includes good oral absorption and lack of metabolism resulting decrease in drug interaction. The presence of the methyl piperazine ring in ofloxacin probably leads to enhanced oral absorption and a long half-life. After oral administration it is excreted in the urine both unchanged $(\approx 70 \%$ of the dose) and as three metabolites (Yuk et al., 1991; Lode et al., 1987).

OFX is made and marketed by several pharmaceutical manufacturer of Nepal. Availability of different formulations of the same drug substance, at the same strength, in the same dosage form and no in-vivo bioequivalence studies to prove their bioequivalence poses a special challenge to health care professionals of this country regarding the therapeutic equivalency of these products. If different formulations have different bioavailability, switching over to new brand may lead to inadequate therapeutic effect, toxicity or even cases of drug resistance can arise (FDA, 2001a; Midha et al., 1998).

This study was performed with an aim to observe the bioavailability of two brands of OFX, Oquin (manufactured by a local manufacturer) and Zanocin which is nationally authorized innovator brand of OFX in Nepal.

\section{Subjects and Methods}

\section{Subjects}

Eight healthy, nonsmoking, adult Nepalese male volunteers (mean age \pm SD, $26.375 \pm 5.449$; range $22-37$ years) were selected for enrollment in the study. The mean body mass index (BMI) of the subjects was $21.395 \pm 2.263 \mathrm{~kg} / \mathrm{m}^{2}$. All had normal renal and hepatic function. Subjects were included in the study after normal findings from physical examination, laboratory investigations (including hematological and biochemical tests, hepatitis and human immunodeficiency virus serological test).

Exclusion criteria were any history of a significant gastrointestinal condition that could potentially impair the absorption or disposition of the study medicine, use of prescribed medication (14 days prior to study) or OTC medication (48 hours prior to study), abuse of alcoholic beverages and history of allergy to the study drug. The volunteers were asked to abstain from taking any medication (including any prescription drugs) throughout the study period.

Prior to any screening procedures, written consent form was obtained from each subject participating in this study after adequate explanation of the aims, methods, objective, and potential hazards of the study.

The study was approved by the Institutional Review Committee of Kathmandu University School of medical Science/Dhulikhel Hospital (IRC-KUSMS). Protocol approval number is IRC-KUSMS 13/07.

\section{Study drugs}

Oquin tablet (OFX 200-mg, batch no. 62161) was used as test formulation. It was provided by Nepal Pharmaceuticals Laboratory, Birgunj, Nepal. Its pharmacokinetic parameters were compared with those of Zanocin (OFX 200-mg, batch no. 1760135), which is manufactured by Ranbaxy Private Limited, India.

*Corresponding author: Rajani Shakya, Department of Pharmacy, Kathmandu University, Nepal, E-mail: rajani.shakya@gmail.com

Received March 16, 2010; Accepted May 08, 2010; Published May 08, 2010

Citation: Shakya R, Hada M, Thapa P, Saha RN (2010) Comparative Bioavailability of Two Brands of Ofloxacin in Healthy Human Volunteers. J Bioequiv Availab 2 : 055-058. doi:10.4172/jbb.1000031

Copyright: @ 2010 Shakya $R$, et al. This is an open-access article distributed unde the terms of the Creative Commons Attribution License, which permits unrestricted use, distribution, and reproduction in any medium, provided the original author and source are credited. 


\section{Study design}

This was an open labeled, two periods, single dose study. On the first study day each volunteer was given one tablet of Oquin $200 \mathrm{mg}$ and in the next study day they receive a tablet of Zanocin. There was 7 days washout period between study days. Each volunteer received the tablet with $240 \mathrm{ml}$ of water. They received standard lunch after 4 , snacks after 8 hrs and dinner after 12 hrs of drug administration. The volunteers were ambulatory throughout the study but were prohibited from strenuous physical activity, smoking, alcohol and stimulating beverages containing xanthine derivatives (tea, coffee, and soft drinks containing caffeine) were also prohibited. Volunteers were monitored constantly throughout the study period by a medical doctor.

\section{Blood sampling}

Blood samples of $5 \mathrm{ml}$ volume were collected in vacutainer tubes (without an anticoagulant) before drug administration and at 0.25 , $0.5,0.75,1,2,3,4,6,8,12,16,24$ hrs after dosing via an intravenous cannula place in the volunteers' forearm. The blood samples were allowed to clot at room temperature for 20 minutes. Then they were centrifuged at $3000 \mathrm{rpm}$ for 15 minutes. Serum was transferred into a separate Eppendorf tubes and was promptly frozen at $-80^{\circ} \mathrm{C}$ until assay. Each tube was properly labeled stating patient identity and time of sampling done after drug administration.

\section{Analysis of ofloxacin concentration in human plasma}

The plasma samples were analyzed using a reversed-phase high performance liquid chromatographic (RP HPLC) method. The isocratic HPLC system (Shimadzu) comprised of a pump (LC - 20AD), autosampler (SIL- 20AD), photo-diode array detector (SPD - M20A) and a column oven (CTO - 10 AS VP). The separation was performed on CAPCELL PAK C18 column $(250 \mathrm{~mm} \times 4.6 \mathrm{~mm} \mathrm{ID} \times 5 \mu \mathrm{m})$ and the wavelength of detector was set at $294 \mathrm{~nm}$.

\section{Pharmacokinetic analysis}

The various pharmacokinetic parameters were calculated using WinNonlin software. The maximum serum concentration $\left(\mathrm{C}_{\max }\right)$ and the time to reach $C \max \left(\mathrm{T}_{\max }\right)$ were determined by visual inspection of the individual serum-concentration time profiles. Terminal elimination rate constant (Kel) was calculated from a semilog plot of the serum concentration versus time curve. The terminal half-life was calculated by the formula $0.693 / \mathrm{kel}$. The area under the concentration-time curve (AUC) calculated by the linear trapezoidal method.

\section{Results}

Single oral dose of Oquin (NPL) or Zanocin (Ranbaxy) were given to eight Nepalese, healthy, male volunteers (mean age \pm SD, 26.375 \pm 5.449; range $22-37$ years) on each study days.

Drug concentrations in serum were assayed by HPLC. The column used was C18 Capcell $25 \mathrm{~mm}$, internal diameter $4.6 \mathrm{~mm}$. The system was operated at $294 \mathrm{~nm}$. Temperature of column oven was set at $40^{\circ} \mathrm{C}$.

Mobile phase consisted of acetonitrile and $0.0625 \%$ triethylamine in water (12.5: 87.5, $\mathrm{pH}$ adjusted to 2.5 with orthophosphoric acid). The mobile phase was prepared daily and delivered at the flow rate of $1.2 \mathrm{ml} / \mathrm{min}$. The retention time for OFX was $10.7 \pm 0.8$ minutes and that for the internal standard (ciprofloxacin) was $13 \pm 0.76$ minutes. The typical assay time is 15 minutes. The software used for data acquisition was LC solution. This method was validated by following international guidelines (Zendelovska and Stafilov, 2005; Shah et al., 2000). The standard curves were linear over the concentration ranges of 0.1 to $5 \mu \mathrm{g} / \mathrm{ml}$. with a correlation coefficient of 0.9999 . The lower limit of quantification of OFX was found to be $0.05 \mu \mathrm{g} / \mathrm{ml}$. The plasma samples of concentration $0.1,0.5,1,2.5$ and $5 \mu \mathrm{g} / \mathrm{ml}$ were prepared in triplicate on each three separate days and analyzed by the method developed. The intra-day and inter-day degree of precision and accuracy of the method is expressed as coefficient of variation and relative error respectively (Table 1). The intraday and interday coefficients of variations were less than $14.42 \%$ for all the selected concentrations. The relative errors at all the studied concentrations were less than $6.2 \%$. These data indicate the considerable degree of precision and reproducibility of the method, both during the analytical run and between different runs. And it is obvious from the relative error that the method is remarkably accurate which ensures that reliable results are obtained.

A single stage liquid-liquid extraction method using methanol (3 times the volume of plasma) was used in this study. This method gave a good recovery (Table 2) with minimal time for extraction.

Pharmacokinetic parameters were calculated using WinNonlin software. The pharmacokinetic analysis after oral dosing of Oquin and Zanocin was based on an open two-compartment model (Lode et al., 1987). The various pharmacokinetic parameters after the administration of OFX $200 \mathrm{mg}$ immediate release formulations manufactured by above mentioned pharmaceutical companies are shown in Table 3.

The mean serum concentration time profile of two formulations as shown in the graph was similar and super imposable (Figure 1). The mean of $\mathrm{C}_{\max }$ was $1.82 \mu \mathrm{g} / \mathrm{ml} \pm 0.19$ (\%CV 10.70) for reference product and $1.98 \pm 0.21 \mu \mathrm{g} / \mathrm{ml}(\% \mathrm{CV} 10.80)$ for test product. For $\mathrm{t}_{\max }$ the mean values were found to be similar for both the reference and test product and it was $2.00 \pm 0.92(\% \mathrm{CV} 48.80)$ for reference and

\begin{tabular}{|c|c|c|c|c|c|c|c|c|}
\hline \multirow{2}{*}{ Concentration added $(\mathrm{mcg} / \mathrm{ml})$} & \multicolumn{2}{|c|}{ Calculated concentration $(\mathrm{mcg} / \mathrm{ml})$} & \multicolumn{2}{|c|}{ Standard deviation } & \multicolumn{2}{|c|}{$\%$ Coefficient of variation } & \multicolumn{2}{|c|}{ Relative error $\%$} \\
\hline & Intra-day & Inter-day & Intra-day & Inter-day & Intra-day & Inter-day & Intra-day & Inter-day \\
\hline 0.1 & 0.096 & 0.104 & 0.013 & 0.015 & 13.541 & 14.42 & -4.000 & 4 \\
\hline 0.5 & 0.531 & 0.522 & 0.011 & 0.024 & 2.071 & 4.597 & 6.2 & 4.4 \\
\hline 1 & 1.015 & 1.015 & 0.062 & 0.044 & 6.104 & 4.334 & 1.5 & 1.5 \\
\hline 2.5 & 2.499 & 2.536 & 0.014 & 0.116 & 0.56 & 4.574 & -0.04 & 1.4 \\
\hline 5 & 4.994 & 5.165 & 0.302 & 0.259 & 6.047 & 5.014 & -0.12 & 3.3 \\
\hline
\end{tabular}

Table 1: Intra-day and inter-day accuracy and precision data.

\begin{tabular}{|c|c|c|c|}
\hline \multirow{2}{*}{$\begin{array}{c}\text { Added concentration } \\
(\mu \mathrm{g} / \mathrm{ml})\end{array}$} & Mean $\pm \mathrm{SD}(\mathrm{n}=3)$ & Absolute recovery $(\%)$ \\
\cline { 2 - 4 } & $93.85 \pm 11.907$ & $80.1-100.75$ & \\
\hline 1 & $93.696 \pm 3.822$ & $89.80-97.44$ & 12.688 \\
\hline 2.5 & $98.269 \pm 5.939$ & $91.88-103.623$ & 4.079 \\
\hline
\end{tabular}

Table 2: Recovery data of OFX at three concentrations. 


\begin{tabular}{|c|c|c|c|}
\hline \multicolumn{4}{|c|}{ Reference formulation, 200-mg Tablet } \\
\hline Pharmacokinetic parameters (no of subjects $=8$ ) & Geometric Mean & SD & CV (\%) \\
\hline $\mathrm{C}_{\max }(\mathrm{mcg} / \mathrm{ml})$ & 1.82 & 0.19 & 10.70 \\
\hline $\mathrm{T}_{\max }(\mathrm{hr})$ & 2.00 & 0.92 & 48.80 \\
\hline $\mathrm{AUC}_{0-24}(\mathrm{mcg} \cdot \mathrm{hr} / \mathrm{ml})$ & 12.56 & 0.96 & 7.70 \\
\hline $\mathrm{AUC}_{0-\infty}(\mathrm{mcg} \cdot \mathrm{hr} / \mathrm{ml})$ & 13.14 & 0.959 & 7.30 \\
\hline $\mathrm{T}_{1 / 2}(\mathrm{hr})$ & 5.55 & 0.715 & 12.90 \\
\hline $\mathrm{K}_{\mathrm{el}}(1 / \mathrm{hr})$ & 0.13 & 0.0174 & 13.40 \\
\hline \multicolumn{4}{|c|}{ Test formulation, Oquin 200-mg Tablet } \\
\hline Pharmacokinetic parameters (no of subjects $=8$ ) & Geometric Mean & SD & CV (\%) \\
\hline $\mathrm{C}_{\max }(\mathrm{mcg} / \mathrm{ml})$ & 1.98 & 0.21 & 10.80 \\
\hline $\mathrm{T}_{\max }(\mathrm{hr})$ & 2.00 & 0.53 & 26.50 \\
\hline $\mathrm{AUC}_{0-24}(\mathrm{mcg} \cdot \mathrm{hr} / \mathrm{ml})$ & 13.19 & 1.45 & 11.00 \\
\hline $\mathrm{AUC}_{0-\infty}(\mathrm{mcg} \cdot \mathrm{hr} / \mathrm{ml})$ & 13.86 & 1.49 & 10.80 \\
\hline $\mathrm{T}_{1 / 2}(\mathrm{hr})$ & 5.55 & 1.37 & 24.80 \\
\hline $\mathrm{K}_{\mathrm{el}}(1 / \mathrm{hr})$ & 0.13 & 0.02 & 19.90 \\
\hline
\end{tabular}

$\mathrm{C}_{\max }(\mathrm{mcg} / \mathrm{ml})=$ peak plasma concentration; $\mathrm{T}_{\max }(\mathrm{hr})$ =time to reach peak serum concentration; $\mathrm{AUC}_{0-24}(\mathrm{mcg}$.hr/ml) =the area under the serum concentration-time curve; $\mathrm{AU}_{\mathrm{CO}-\infty}(\mathrm{mcg} . \mathrm{hr} / \mathrm{ml})=$ the area under the serum concentration-time curve extrapolated to infinity; $\mathrm{T}_{1 / 2}(\mathrm{hr})=$ serum elimination half life; $\mathrm{K}_{\mathrm{el}}(1 / \mathrm{hr})=\mathrm{elimination}$ rate constant; $\mathrm{CV}=$ coefficient of variation; $\mathrm{SD}=$ standard deviation

Table 3: Mean pharmacokinetic parameters of OFX 200-mg tablets

$2.00 \pm 0.53(\% \mathrm{CV} 26.50)$ for test product. For AUC $0-24$, the values obtained were $12.56 \pm 0.96(\% \mathrm{CV} 7.70) \mu \mathrm{g} . \mathrm{hr} / \mathrm{ml}$ and $13.19 \pm 1.45$ (\%CV 11.0) $\mu \mathrm{g} . \mathrm{hr} / \mathrm{ml}$ for reference and test product respectively.

AUC is important in determining the BA and BE of a drug product. The values of $\mathrm{AUC}_{0-24}$ for all volunteers were found to be greater than $80 \%$ of $\mathrm{AUC}_{0-\infty}$. The mean $\mathrm{AUC}_{0-\infty}$ values were found to be $13.14 \pm$ $0.959(\% \mathrm{CV} 7.30) \mu \mathrm{g} . \mathrm{hr} / \mathrm{ml}$ for reference and $13.86 \pm 1.49(\% \mathrm{CV} 10.80)$ $\mu \mathrm{g} . \mathrm{hr} / \mathrm{ml}$ for test product. Half-life of OFX was found to be $5.55 \mathrm{hr}$ ( $5.55 \pm 1.37 \mathrm{hr}$ for test product, $5.55 \pm 0.715$ for reference), Kel was $0.13 \pm 0.0174(\% \mathrm{CV} 13.40)$ for reference and $0.13 \pm 0.02(\% \mathrm{CV} 19.90)$ for test.

The table 4 shows the $90 \%$ confidence intervals of ratio of test and reference (T/R) between the 2 formulations regarding $\mathrm{AUC}_{0-24}, \mathrm{AUC}_{0}$ and $\mathrm{C}_{\max }$. Ratio of Least square Means (T/R) percent was found to be 105.159 for $\mathrm{AUC}_{0-24}, 105.506$ for $\mathrm{AUC}_{0-\infty}$ and 111.394 for $\mathrm{C}_{\max }$. The study revealed that at a $90 \%$ confidence interval, $\mathrm{AUC}_{0-24}, \mathrm{AUC}_{0-\infty}$ and $\mathrm{C}_{\max }$ were found to be within the range of $97.81 \%$ and $113.07 \%, 98.59 \%$ and $112.93 \%$, and 102.14 and $121.47 \%$ respectively. All of these values are within the bioequivalence accepted range of $80 \%$ - $125 \%$; however, the sample size in this study is not sufficient to provide significant

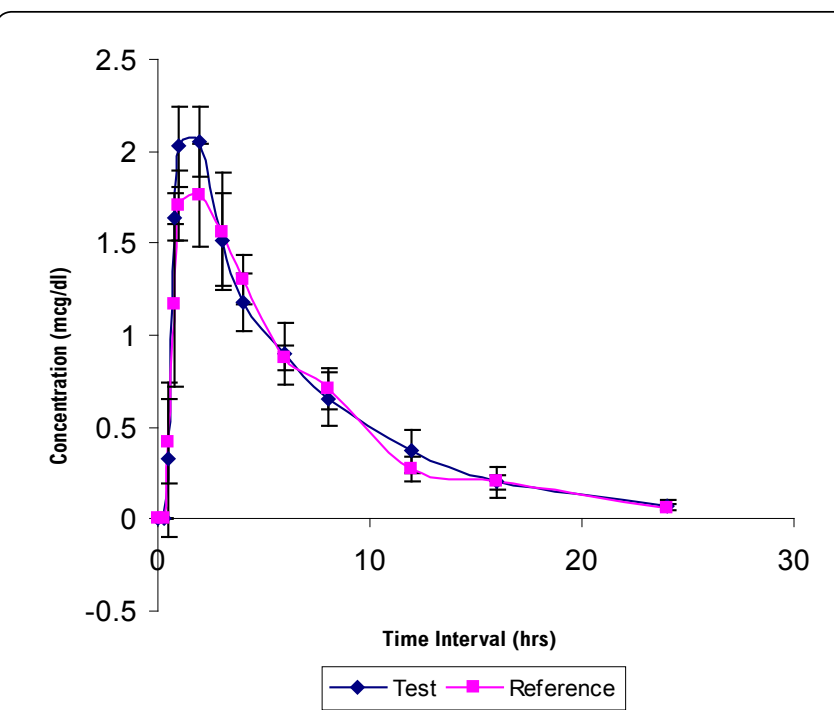

Figure 1: Mean plasma concentrations of OFX after oral administration of 200$\mathrm{mg}$ tablet of reference (Zanocin) and test (Oquin) to 8 healthy male volunteers.

\begin{tabular}{|l|l|l|l|}
\hline \multicolumn{4}{|c|}{$\begin{array}{c}\text { Test /Reference } \\
\text { Log transformed data }\end{array}$} \\
\hline Parameters & Mean Ratio (Test/Reference) & $90 \% \mathrm{Cl}$ \\
\hline $\mathrm{AUC}_{0-24}(\mathrm{mcg} \cdot \mathrm{hr} / \mathrm{ml})$ & 105.159 & 97.81 & 113.07 \\
\hline $\mathrm{AUC}_{0-\infty}(\mathrm{mcg} \cdot \mathrm{hr} / \mathrm{ml})$ & 105.506 & 98.58 & 112.93 \\
\hline Cmax $(\mathrm{mcg} / \mathrm{ml})$ & 111.394 & 102.14 & 121.47 \\
\hline
\end{tabular}

Table 4: $90 \%$ Confidence interval for different pharmacokinetic parameters from log data for assessment of bioequivalence.

power for concluding these two products bioequivalent. But it is apparent that pharmacokinetic parameters including bioavailability for both of these products are comparable and these products can be proven bioequivalent in a study with sufficient number of volunteers.

\section{Discussions}

BA and BE studies provide important information which ensure safety and effectiveness of medicines to patients and practitioners. Providing two drug products bioequivalent entails a similarity in rate and extent to which a drug in a dosage form becomes available for biological absorption. Area under the curve is accepted as a good indicator of the extent of absorption, whereas $C_{\max }$ and $T_{\max }$ are considered estimators of ratio of absorption (FDA, 2001a; GIBB, 2001; FDA-OGD, 1992; FDA, 2001b).

The aim of this study was to compare the bioavailability of two formulations of OFX 200-mg tablets, Zanocin (reference formulation) and Oquin (test formulation). The study revealed that pharmacokinetic parameters of these two products are almost similar and OFX concentration-time profiles generated by the two products were essentially super-imposable.

The PK parameters obtained were in good agreement with those reported in literature. Study done by Lode et al. (1987) shows similar type of result $\left(\mathrm{C}_{\max }=1.19 \pm 0.43, \mathrm{t}_{\max } 76.8 \pm 39.2\right.$ mins, $\mathrm{AUC}_{0-\infty}$ $14.6 \pm 2.7$ ) (Lode et al., 1987). Other two crossover study of comparison of two formulations of $200 \mathrm{mg}$ tablet of OFX studies have reported were slightly different but comparable with that of the present study (Oliveira et al., 1999; Flor et al., 1991).

It can be concluded that PK values of OFX obtained from test (Oquin) and reference were comparable in the extent of bioavailability $\left(\mathrm{AUC}_{0-\infty}\right.$ and $\left.\mathrm{C}_{\max }\right)$ and in the rate of absorption $\left(\mathrm{C}_{\max }\right.$ and $\left.\mathrm{T}_{\max }\right)$. They can be proven bioequivalent in a crossover bioequivalence study. 
Citation: Shakya R, Hada M, Thapa P, Saha RN (2010) Comparative Bioavailability of Two Brands of Ofloxacin in Healthy Human Volunteers. J Bioequiv Availab 2: 055-058. doi:10.4172/jbb.1000031

\section{Acknowledgement}

The authors wish to express their hearty gratitude to Nepal Pharmaceutical Laboratories (Pvt) Ltd for providing equipments and necessary chemicals for the study.

\section{References}

1. Balthasar JP (1999) Bioequivalence and Bioequivalence Testing. Am J Pharm Educ 63: 194-198. " CrossRef » PubMed " Google Scholar

2. Food and drug administration (2001a) Guidance for industry: Statistical approaches to establishing bioequivalence. »CrossRef » PubMed » Google Scholar

3. Food and drug administration (2001b) Guidance for industry: Statistical approaches to establishing bioequivalence. »CrossRef » PubMed » Google Scholar

4. Food and Drug Administration-Office of Generic Drugs (1992) Division of Bioequivalence, Guidance on statistical procedures for bioequivalence studies using a standard two-treatment crossover design. " CrossRef " PubMed " Google Scholar

5. Flor S, Guay D, Opsahl J, Tack K, Matzke G (1991) Pharmacokinetics of Ofloxacin in healthy subjects and patients with varying degrees of renal impairment. Intl J Clin Pharmacol 11: 115-21. » CrossRef » PubMed " Google Scholar

6. Guidance on the Investigation of Bioavailability and Bioequivalence (2001) The European Agency for the Evaluation of medicinal products, Evaluation of Medicines for Human Use. " CrossRef » PubMed » Google Scholar
7. Lode H, Höffken G, Olschewski P, Sievers B, Kirch A, et al. (1987) Pharmacokinetics of Ofloxacin after Parental and Oral Administration. Antimicrob Agents Chemother 31: 1338-1342. » CrossRef » PubMed » Google Scholar

8. Midha KK, Rawson MJ, Hubbard JW (1998) Bioequivalence: Switchability and scaling. Eur J Pharm Sci 6: 87-91. »CrossRef » PubMed » Google Scholar

9. Okeri HA, Arhewoh IM (2008) Analytical Profile of the Fluoroquinolone Antibacterials. I. Ofloxacin. Afr J Biotechnol 7: 670-680. » CrossRef » PubMed " Google Scholar

10. Oliveira CF, Dias HB, Ribeiro W, Poli A, Peixoto AP, et al. (1999) Comparative bioavailability of two capsule formulations of Ofloxacin in healthy volunteers after a single dose administration. Clin Res Pr Drug Regul Aff 16: 29-40. "CrossRef " PubMed " Google Scholar

11. Shah VP, Midha KK, Findlay JW, Hill HM, Hulse JD, et al. (2000) Bioanalytical method validation-a revisit with a decade of progress. Pharm Res 17:15511557. "CrossRef " PubMed » Google Scholar

12. Yuk JH, Nightingale CH, Quintiliani R, Sweeney KR (1991) Bioavailability and pharmacokinetics of ofloxacin in healthy volunteers. Antimicrob Agents Chemother 35: 384-386. » CrossRef » PubMed " Google Scholar

13. Zendelovska D, Stafilov T (2005) Development and validation of highperformance liquid chromatographic method for determination of ofloxacin and lomefloxacin in human plasma. J Serb Chem Soc 12: 1451-1460. „CrossRef » PubMed » Google Scholar 